[J.Jpn.Soc.Starch Sci., Vol. 32, No. 3, p. 213 216(1985)]

\title{
Quantitative Determination of Disaccharides Produced from Soluble Starch through Transglucosylation of Buckwheat $\alpha$-Glucosidase
}

\author{
Seiya Chiba, Atsuo Kimura, Takeshi Kobori and \\ Keiko SAITOH \\ Department of Agricultural Chemistry, Faculty of Agriculture, Hokkaido University \\ (Nishi 9, Kita 9, Kita-ku, Sapporo 060, Japan) \\ (Received February 4, 1985)

\begin{abstract}
A gas-liquid chromatographic method was examined in order to determine kojibiose and maltose in their mixture. The two disaccharides proved to be determined by this method, in which they were estimated from the ratio between the heights of the peaks on the gas-liquid chromatogram of $\alpha$-maltose and $\alpha$-kojibiose. The amounts of disaccharides produced from soluble starch through the transglucosylation of buckwheat $\alpha$-glucosidase were quantitatively determined for the first time by a combination of a gas-liquid and a paper chromatographic methods. In the initial stage of the transglucosylation of the $\alpha$-glucosidase, kojibiose, nigerose and maltose were remarkably formed, and isomaltose was the minor product. However, isomaltose was gradually accumulated, and other disaccharides disappeared rapidly with the elapse of reaction time.
\end{abstract}

Buckwheat $\alpha$-glucosidase has been reported to be a transglucosylase which catalyzes predominant formation of $\alpha-1,2-, \alpha-1,3-$ or $\alpha-1,4$ glucosidic linkage. ${ }^{1,2)}$ This enzyme is capable of synthesizing readily kojibiose, nigerose or maltose from soluble starch. However, the amounts of individual disaccharides produced through the transglucosylation have not been quantitatively determined so far. For this reason, it may be pointed out that it is difficult to separate chromatographically maltose and kojibiose each other. There has been no report on the method for simultaneous determination of kojibiose and maltose.

We intend to apply a gas-liquid chromatographic method to determination of kojibiose and maltose in their mixture. The present paper describes the establishment of a method for quantitative analyses of kojibiose and maltose, and the determination of disaccharides formed from soluble starch through the transglucosylation of buckwheat $\alpha$-glucosidase. Kojibiose, nigerose, maltose and isomaltose in the reaction mixture were determined for the first time by a combination of the gas-liquid chromatographic method and a paper chromatographic method.

\section{MATERIALS AND METHODS}

Chemicals. Glucose, maltose and soluble starch were purchased from the Nakarai Chemical Co., Ltd. To remove the impurities, maltose was purified by recrystallization, and soluble starch was done by thorough washing with cold water. Nigerose, kojibiose and isomaltose were enzymatically synthesized through the transglucosylation of buckwheat $\alpha$-glucosidase. $^{11}$

A trimethylsilylation reagent (TMSI-H) containing hexamethyldisilazane and trimethylchlorosilane in pyridine was obtained from a 
commercial source (the Gasukuro Kogyo Co., Ltd.).

Enzyme. Buckwheat $\alpha$-glucosidase was homogeneously prepared from commercial buckwheat seeds according to the method described in the reference cited. ${ }^{3)}$ One unit of $\alpha$-glucosidase activity was defined as the amount of enzyme which hydrolyzed $1 \mu \mathrm{mol}$ of maltose per min under the following conditions; the reaction mixture, consisting of $0.8 \mathrm{ml}$ of $0.5 \%$ maltose, $0.8 \mathrm{ml}$ of $0.1 \mathrm{M}$ sodium acetate buffer ( $\mathrm{pH} 5.0)$ and enzyme solution in a final volume of $2 \mathrm{ml}$, was incubated at $37^{\circ} \mathrm{C}$. Glucose liberated by the enzyme reaction was measured by the Tris-glucose oxidase-peroxidase method ${ }^{4,5)}$ with some modifications by us using a "Glucose AR-Test" (the Wako Pure Chemical Ind., Ltd.).

Trimethylsilylation. A mixture of $\alpha$ - and $\beta$-maltose or $\alpha$-and $\beta$-kojibiose, of which total amount was $2 \mathrm{mg}$, was equilibrated by maintaining at $110^{\circ} \mathrm{C}$ for $5-10 \mathrm{~min}$, followed by drying and subjecting to trimethylsilylation. Carbohydrates were converted to trimethylsilyl compounds by incubation with $0.3 \mathrm{ml}$ of TMSI-H at $80^{\circ} \mathrm{C}$ for $10 \mathrm{~min}$, and the trimethylsilyl (TMS) derivatives were subjected to gas-liquid chromatography.

Gas-liquid chromatography. Gas-liquid chromatography (GLC) was performed on a Hitachi Model 063 gas-liquid chromatograph equipped with a hydrogen flame-ionization detector. A stainless steel column $(0.3 \times 200 \mathrm{~cm})$ packed with $3 \%$ Silicon SE-30 on Chromosorb WAW-DMCS (60-80 mesh) was employed. Nitrogen was used as the carrier gas at a flow rate of $30 \mathrm{ml}$ per min.

Paper chromatography. Paper chromatography (PPC) was carried out by a multiple ascending technique (three times) on Toyo Roshi No. 50 filter paper. The solvent system was 1-butanol, pyridine and water $(6: 4: 3$, by volume). The carbohydrates were detected with anisidine-phthalate (APT) reagent. ${ }^{6}$ ) The sugar extracted from paper was determined by the phenol-sulfuric acid method. ${ }^{7}$

\section{RESULTS AND DISCUSSION}

Examination of analytical method of maltose and kojibiose in their mixture

Figure 1 shows the gas-liquid chromatograms
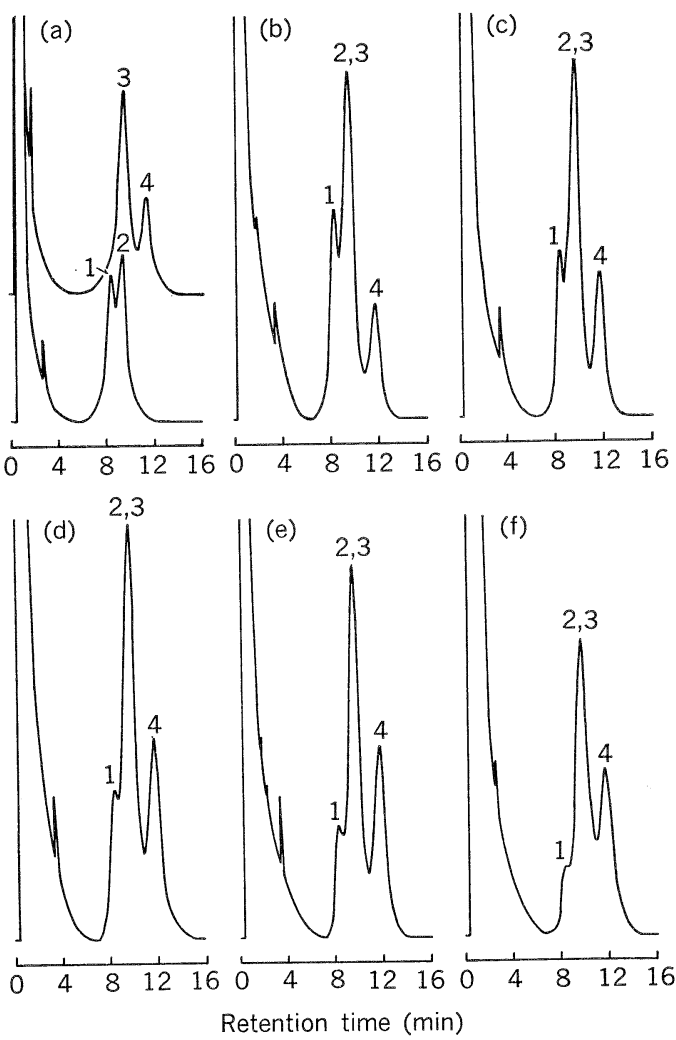

Fig. 1. Gas-liquid chromatograms of TMS-derivatives from maltose and kojibiose.

Column temperature, $250^{\circ} \mathrm{C}$; injection port temperature, $290^{\circ} \mathrm{C}$; detector temperature, $290^{\circ} \mathrm{C} .1$, $\alpha$-maltose; $2, \beta$-maltose; $3, \beta$-kojibiose; $4, \alpha$-kojibiose. a, maltose and kojibiose; b, c, d, e and $\mathrm{f}$, the mixtures of maltose and kojibiose, in which the molar ratios of maltose to kojibiose are $1: 1$ (b), $2: 3$ (c), $1: 2$ (d), $1: 3$ (e) and $1: 4$ (f).

of the equilibrium mixtures of $\alpha$ - and $\beta$ anomers of maltose or kojibiose. The two disaccharides can not be separated from each other in GLC (Fig. 1a), but $\alpha$-maltose and $\alpha$-kojibiose are separately eluted at different retention times. This implies that the content of maltose or kojibiose in their mixture may be estimated from the ratio between the heights of the peak of $\alpha$-maltose and $\alpha$-kojibiose.*

* In our previous paper, ${ }^{8)}$ unfortunately, we made a mistake in the description of the data of GLC, in which the retention times of $\alpha$-kojibiose and $\beta$-kojibiose were erroneously stated in the reverse order. 


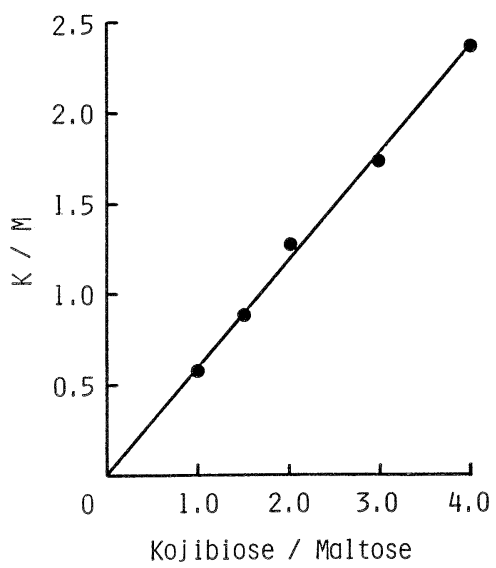

Fig. 2. Calibration curve of maltose and kojibiose.

Ordinate: the ratios of the peak height $(M)$ of $\alpha$-maltose to the peak height $(K)$ of $\alpha$-kojibiose; abscissa: the molar ratios of maltose to kojibiose. Carbohydrates $(2 \mathrm{mg}$ ) were trimethylsilylated with TMSI-H $(0.3 \mathrm{ml})$.

The gas-liquid chromatograms of the mixtures of various proportions of maltose and kojibiose equilibrated are shown in Fig. $1 \mathrm{~b}, \mathrm{c}, \mathrm{d}$, e and $f$. The calibration curve for quantitative determination is demonstrated in Fig. 2, in which the ratios of the peak height $(M)$ of $\alpha$-maltose to the peak height $(K)$ of $\alpha$-kojibiose are plotted against the ratios of maltose to kojibiose in weight. Individual amounts of the two disaccharides can be readily obtained by using this calibration curve. This method proved to be useful for simultaneous determination of maltose and kojibiose.

Determination of transglucosylation products from soluble starch by buckwheat a-glucosidase

The reaction mixture $110 \mathrm{ml}$, consisting of $11 \mathrm{~g}$ of soluble starch and 28 units of the enzyme in $0.02 \mathrm{M}$ sodium acetate buffer $(\mathrm{pH} 5.0)$, was incubated at $37^{\circ} \mathrm{C}$. Ten milliliters of the reaction mixture was pipetted out at definite time intervals, and then boiled for $5 \mathrm{~min}$ to terminate the reaction.

To each reaction mixture was added ethanol up to $60 \%$ to separate remaining soluble starch, and the resulting precipitate was filtered out. Figure 3 shows the paper chromatogram of the products, where the spots of maltose and kojibiose overlap each other. Each filtrate was

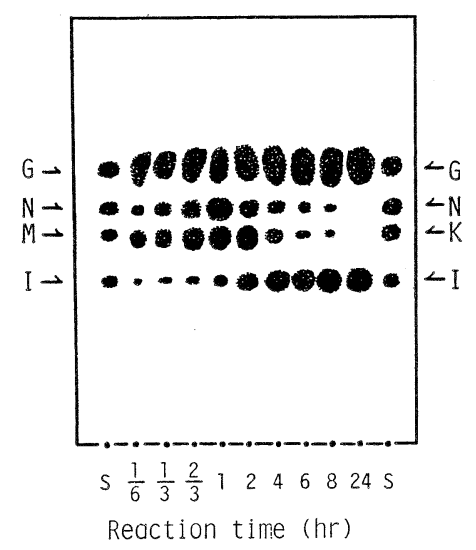

Fig. 3. Paper chromatogram of the products from soluble starch by buckwheat $\alpha$-glucosidase.

$\mathrm{S}$, standard; G, glucose; N, nigerose; M, maltose; $\mathrm{I}$, isomaltose; $\mathrm{K}$, kojibiose.

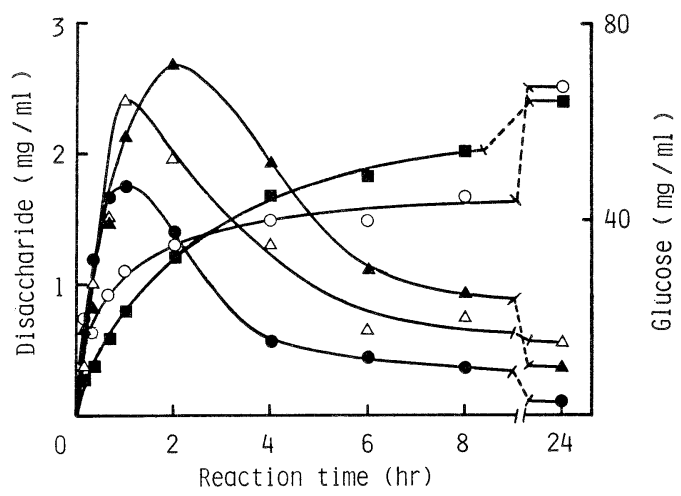

Fig. 4. Time courses of formations of carbohydrates from soluble starch by buckwheat $\alpha$-glucosidase.

Ordinate: $\mathrm{mg}$ of each product per $\mathrm{ml}$ of the reaction mixture. - maltose; $\bigcirc$, isomaltose; $\boldsymbol{\Delta}$, kojibiose; $\triangle$, nigerose; $\mathbf{a}$, glucose.

dried in vacuo and then dissolved in $3 \mathrm{ml}$ of water, followed by paper chromatography for the determination of products at definite time intervals. The zones corresponding to the spots of glucose, nigerose, maltose (and kojibiose) and isomaltose were cut out from the paper. The content of sugar extracted with hot water from each strip was measured by the phenolsulfuric acid method. ${ }^{6}$ )

Furthermore, the relative content of maltose and kojibiose was measured by a gas-liquid 
chromatographic method mentioned above. Figure 4 shows the time courses of formations of sugars from soluble starch by buckwheat $\alpha$-glucosidase. In the initial stage of transglucosylation, kojibiose, nigerose and maltose were remarkably formed, and isomaltose was the minor product. However, isomaltose was gradually accumulated because of being less susceptible to hydrolysis by this enzyme ${ }^{9}$ though other disaccharides disappeared rapidly with the elapse of reaction time. A gas-liquid chromatographic method mentioned above had first enabled us to determine quantitatively the amounts of disaccharides produced from soluble starch through the transglucosylation of buckwheat $\alpha$-glucosidase.

This study was supported by a Grant-in-Aid for Scientific Research from the Ministry of Education, Science and Culture of Japan.

\section{REFERENCES}

1) M. TAKahashi, T. Shimomura and S. Chiba: Agric. Biol.Chem., 33, 1399 (1969).

2) S. Chiba and T. Shimomura: J.Jpn. Soc. Starch Sci., 26, 59 (1979).

3) K. Kanaya, S. Chiba, T. Shimomura and K. NishI: Agric.Biol.Chem., 40, 1929 (1976).

4) N. M. PAPAdopoulos and W. C. Hess: Arch. Biochem. Biophys., 88, 167 (1977).

5) A. DAHLQVIST: Biochem.J., 80, 547 (1961).
6) A. Schweiger: J. Chromatogr., 9, 374 (1962).

7) M. Dubois, K. A. Gilles, J. K. Hamilton, P. A. Rebers and F. Smith: Anal.Chem., 28, 350 (1956).

8) S. Chiba, S. Okada, S. Kitahata and T. SHImomura: Agric. Biol. Chem., 39, 2353 (1975).

9) S. Chiba, K. Kanaya, K. Hiromi and T. SHIMOMURA: Agric. Biol. Chem., 43, 237 (1979).

ソバ $\alpha$-グルコシダーゼの糖転移作用により

可溶性澱粉から生成される二糖類の定量

千葉誠哉, 木村淳夫, 小堀 武, 斉藤恵子

北海道大学農学部農芸化学科生物化学講座 (060 札幌市北区北 9 条西 9 丁目)

コージビオースとマルトースの混合物から両者を定量 するためにガスクロマトグラフィーによる定量法を検討 し， $\alpha$-マルトース括よび $\alpha$-コージビオースのピーク比 から両者を測定できることを見出した。同方法拈よびぺ ーパークロマトグラフィーを組み合わせることにより，

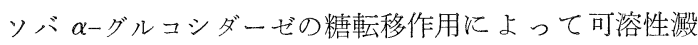
粉から生成される二糖類を初めて経時的に定量すること ができた、反応初期ではコージビオース，ニゲロース， マルトースの著しい生成が認められたが，イソマルトー スの生成量は少なかった. 反応の経過沉伴い,イソマル トースは徐々に増加したが，他の二糖類は速やかに減少 した。 